\title{
Improving Student Learning Achievement through Behavior Modification Approach
}

\author{
Imam Gunawan \\ Educational Administration \\ Universitas Negeri Malang \\ Malang, Indonesia \\ imam.gunawan.fip@um.ac.id \\ Hana Andriningrum \\ Elementary School Teacher Education \\ Universitas Negeri Malang \\ Malang, Indonesia \\ hansiphana@gmail.com
}

\author{
Suminah \\ Elementary School Teacher Education \\ Universitas Negeri Malang \\ Malang, Indonesia \\ suminahpp3@yahoo.co.id
}

\author{
Sri Murdiyah \\ Elementary School Teacher Education \\ Universitas Negeri Malang \\ Malang, Indonesia \\ sri.murdiyah.fip@um.ac.id \\ Gena Onenda \\ Elementary School Teacher Education \\ Universitas Negeri Malang \\ Malang, Indonesia \\ genaonenda.personal@gmail.com
}

\begin{abstract}
The purpose of this research is to improve student learning achievement through behavior modification approach in Grade V Elementary School Laboratory State University of Malang (UM) Blitar City East Java Indonesia. This research was conducted using a classroom action research method in two cycles. The subjects of this research are 27 students. Data were analyzed with descriptive statistics. Furthermore, by using stanfive formula, data is arranged with the frequency distribution table. Data analyse by comparing the results of the scores obtained from Cycle I and Cycle II (student achievement data). Data analysis use analysis of variance paired-samples t-test formula with the help of SPSS PASW Statistics 18. The result of research are (1) student achievement level through behavior modification approach included in category good enough; and (2) there is an improvement of student achievement through behavior modification approach.
\end{abstract}

Keywords-behavior modification approach, learning achievement, elementary school

\section{INTRODUCTION}

A nation's development can be seen from the withdrawal of education. National education is a process that is conscious of goals. The aim of national education is to develop the potential of students to become faithful and fearful people of God Almighty, noble, knowledgeable, capable, creative, independent, and be democratic and responsible citizens. Education will succeed if it is supported by good learning outcomes.

Learning achievement is the level of knowledge that learners achieve on material received when attending and doing tasks and learning activities [1]. Learning achievement is the ability obtained by the individual after the learning process takes place, which can provide changes in behavior both knowledge, understanding, attitudes, and skills of learners to be better than ever [2]. Student learning achievement is the form of cognitive, psychomotor, and affective aspects [3]. Cognitive aspects include mastery of concepts and principles as well as problem-solving performance. Psychomotor aspects of physical skills in conducting experiments (observations). While the affective aspect is the attitude of learners to the lessons and learning.

If it refers from the opinion expressed by the experts, it can be concluded that the learning achievement is the ability possessed both the attitude (affective), knowledge (cognitive), and skills (psychomotor) that all this is obtained through the process of teaching and learning. The behavioraltering approach is based on the principles of behavioral psychology. The main principle underlying this approach is that behavior is the result of the learning process. This principle applies to both appropriate behavior and deviant behavior. The approach to behavioral change is built on two basic assumptions: (1) there are four processes that need to be taken into account in learning for all people of all ages and in all circumstances; and (2) the learning process is partially or wholly influenced (controlled) by events occurring in the environment.

The main task of the teacher thus is to master and apply the four proven processes (for the behaviorists) is the controller of human behavior, namely: (1) positive reinforcement; (2) punishment; (3) removal; and (4) negative reinforcement. The behavior modification approach is based on the principles of behavioral psychology [4]. Learning achievement is a student achievement in learning [5]. Student motivation is an encouragement that makes students' passion for learning [6]. The studies of the behavior modification approach and student achievement become crucial to do by doing a research.

\section{METHOD}

Research conducted is qualitative research. This research was conducted using a classroom action research method. Classroom action research design taken namely the cycle model, which is carried out repeatedly continuous (spiral cycle). The cycle model is compiled such that so that in each cycle consists of: planning, action, observation and reflection.

The research was conducted in Grade V Elementary School Laboratory State University of Malang (UM) Blitar City East Java Indonesia, with the number of research subjects as many as 27 students. This study was conducted in two cycles. Data collection techniques used in this study is a test. Referring to the data collection techniques, the instruments for collecting data used in this study are student achievement test. Student achievement data obtained from the list of test scores of students from tests conducted by teachers.

Data on learning achievement in question is the value of the task and exam daily students. Data were analyzed 
descriptively by using percentage technique to see the tendency that happened in a learning activity. Data were analyzed by descriptive statistic, ie calculating the mean $(\overline{\mathrm{X}})$ and standard deviation (SD) ([7],[8]). Furthermore, by using stanfive formula (Table I), the data is arranged with the frequency distribution table, for learning achievement variable and student's learning motivation.

TABLE I. Stanfive Formulas

\begin{tabular}{|l|l|l|}
\hline No & \multicolumn{1}{|c|}{ Formula } & \multicolumn{1}{c|}{ Category } \\
\hline 1 & $(\overline{\mathrm{X}}+1.5 \mathrm{SD})<\mathrm{X}$ & Very good \\
\hline 2 & $(\overline{\mathrm{X}}+0.5 \mathrm{SD})<\mathrm{X}<(\overline{\mathrm{X}}+1.5 \mathrm{SD})$ & Good \\
\hline 3 & $(\overline{\mathrm{X}}-0.5 \mathrm{SD})<\mathrm{X}<(\overline{\mathrm{X}}+0.5 \mathrm{SD})$ & Good enough \\
\hline 4 & $(\overline{\mathrm{X}}-1.5 \mathrm{SD})<\mathrm{X}<(\overline{\mathrm{X}}-0.5 \mathrm{SD})$ & Less good \\
\hline 5 & $\mathrm{X}<(\overline{\mathrm{X}}-1,5 \mathrm{SD})$ & Bad \\
\hline
\end{tabular}

Data analysis is by comparing the results of the scores obtained from Cycle I and Cycle II (student achievement data). The data analysis is a variance analysis of pairedsamples t-test formula with the help of SPSS PASW Statistics 18. Paired-samples t-test compares the differences in the means of the paired samples [10]. Paired-samples t-test was performed on two paired samples, paired samples were defined as a sample with the same subject but experienced two different treatments or measurements, such as subject A will receive the treatment I and then get treatment II [11].

\section{RESULT}

The score of student achievement obtained from an accumulated score of duty and student's daily test. Table II is the frequency distribution of student achievement score in Cycle I. Based on Table II it is known that from 27 students who are in the interval score: $>92.87$ as many as 3 students $(11.11 \%)$ with very good category; $87.05-92.87$ as many as 8 students $(29.63 \%)$ with good category; $81.24-87,05$ as many as 5 students (18.52\%) with good enough category; $75.43-81.24$ as many as 10 students $(37.04 \%)$ with less good category; and < 75.43 as many as 1 student $(3.70 \%)$ with bad category. Student achievement score Cycle I obtained average 84.15 and standard deviation of 5.81 . Based on Table II it can be concluded that the level of student achievement score on Cycle I with the average of 84.15 included in the category is good enough.

TABLE II. FREQUENCY DISTRIBUTION OF STUDENT LEARNING ACHIEVEMENT (CYCLE I)

\begin{tabular}{|l|l|l|l|l|}
\hline No & \multicolumn{1}{|c|}{ Interval } & \multicolumn{1}{|c|}{ F } & \multicolumn{1}{|c|}{ Category } & \multicolumn{1}{|c|}{} \\
\hline 1 & $>92.87$ & 3 & 11.11 & Very good \\
\hline 2 & $87.05-92.87$ & 8 & 29.63 & Good \\
\hline 3 & $81.24-87.05$ & 5 & 18.52 & Good enough \\
\hline 4 & $75.43-81.24$ & 10 & 37.04 & Less good \\
\hline 5 & $<75.43$ & 1 & 3.70 & Bad \\
\hline$\sum$ & $\mathbf{2 7}$ & $\mathbf{1 0 0}$ & \\
\hline
\end{tabular}

Table III is the frequency distribution of student achievement score in Cycle II. Based on Table III it is known that from 27 students who are in the interval score: $>93.08$ as many as 3 students $(11.11 \%)$ with very good category; $87.49-93.08$ as many as 7 students $(25.93 \%)$ with good category; 81.90 - 87,49 as many as 5 students $(18.52 \%)$ with good enough category; 76.31 - 81,90 as many as 11 students $(40.74 \%)$ with the less good category; and $<76.31$ as many as 1 student $(3.70 \%)$ with bad category. The score of student achievement of Cycle II was obtained the mean of 84.70 and standard deviation of 5.59. Based on Table III it can be concluded that the level of student achievement score in Cycle I with average 84.70 included in the category is good enough.

TABLE III. FREQUENCY DISTRIBUTION OF STUDENT LEARNING ACHIEVEMENT (CYCLE II)

\begin{tabular}{|l|l|l|l|l|}
\hline No & \multicolumn{1}{|c|}{ Interval } & \multicolumn{1}{|c|}{ F } & \multicolumn{1}{|c|}{ Category } & \multicolumn{1}{|c|}{} \\
\hline 1 & $>93,08$ & 3 & 11.11 & Very good \\
\hline 2 & $87.49-93.08$ & 7 & 25.93 & Good \\
\hline 3 & $81.90-87.49$ & 5 & 18.52 & Good enough \\
\hline 4 & $76.31-81.90$ & 11 & 40.74 & Less good \\
\hline 5 & $<76.31$ & 1 & 3.70 & Bad \\
\hline$\sum$ & & $\mathbf{2 7}$ & $\mathbf{1 0 0}$ & \\
\hline
\end{tabular}

Furthermore, the data of student achievement score on Cycle I and Cycle II was tested by analysis of variance paired-samples t-test formula with the help of SPSS PASW Statistics 18. The result of variance analysis of the pairedsamples t-test formula with SPSS PASW Statistics 18 found that the significance value of 0.000 (Table IV). Based on the results of the paired-samples t-test analysis using a significance level of 0.05 can be seen that the value of significance obtained by $0.000<0.05$. So Ho rejected and Ha not rejected. Thus it can be concluded that there is an increase in student achievement from Cycle I to Cycle II by using a behavior modification approach.

TABLE IV. PAIRED-SAmples T Test Student ACHIEVEMENT CyCle I AND CYCLE II

\begin{tabular}{|l|l|l|c|c|c|c|}
\hline \multicolumn{1}{|c|}{ Cycle } & \multicolumn{1}{|c|}{ N } & Average & Min & Max & SD & p \\
\hline I & 27 & 84.15 & 74,72 & 94,26 & 5,81 & \multirow{2}{*}{0,000} \\
\hline II & 27 & 84.70 & 75,65 & 94,22 & 5,59 & \\
\hline
\end{tabular}

\section{DISCUSSION}

The results showed the level of student achievement through behavior modification approach included in the category quite well. The result of the research concludes that there is an improvement of student achievement through behavior modification approach in Grade V SD Laboratory of State University of Malang (UM) Blitar City East Java Indonesia. The results of this study in accordance with research conducted by Tarigan [12] which concludes student achievement by using behavior modification method to be better. Behavior modification method is one of the concrete efforts that can be implemented by teachers to overcome the difficulties of students in understanding and mastering the concept thoroughly [13].

Arends [14] states efforts to improve student achievement can be by applying behavior modification learning. The results of Tarsih, et.al., [15] concluded that behavior change behavior is done by growing the students' problem-solving skills, either independently or in groups, enabling the students to discuss each other, so that each student is responsible for the task and improving student's learning achievement. Implementation of this behavior modification model is to improve the accuracy of pronunciation in children; teachers are always attentive to the 
learning behavior of learners; modification of learners behavior with low learning ability with a reward as reinforcement support; application of the principle of individual learning in classical learning [16].

Characteristics of behavior modification are: (1) emphasizing the definition of the problem in terms of behavior, change in behavior becomes an indicator of problem solving; (2) procedures and techniques covering the means of environmental regulation; (3) the methods and reasons may be clearly described; (4) the technique derived from laboratory research, now an experimental psychology; (5) in behavioral modification, learning psychology, and conditioning principles are the most useful / widely used principles; (6) emphasizes the use of scientific methods to make it clear that certain interventions are indeed responsible for behavioral change; and (7) attach importance to all parties involved in the modification of client behavior [17].

Behavior modification technique is a technique of selfinstruction and self-monitoring ([18]; [19]). Self-instruction is done so that counselees can teach themselves how to deal effectively with difficult situations for themselves [20]. Selfmonitoring to record his behaviors so that he can monitor his behavior at any time to get the behavior he hopes. Behavior modification approach is an approach based on the assumption that human beings can increase their capacity in managing learning stress by changing their beliefs, emotions, and behaviors about the success of dealing with stress independently [21].

Syarifuddin [22] concluded that the behavior modification approach can affect student achievement. External factors that affect learning achievement in relation to the implementation of the behavior modification approach are the teacher and how to teach it, opportunities available, and social motivation [23]. The main principle underlying this behavior modification approach is behavior is the result of the learning process. This principle applies to appropriate behavior as well as deviant behavior [24].

\section{CONCLUSION}

Based on the results of data analysis, the conclusions of this study are: (1) the level of student achievement through behavior modification approach included in the category is quite good; and (2) there is improvement of student achievement through behavior modification approach in Grade V SD Laboratory State University of Malang (UM) Blitar City East Java Indonesia. The results of this study support the theory that class management by using behavior modification approach is very effective to improve student achievement.

\section{ACKNOWLEDGMENT}

Thanks to Dean of the Faculty of Education, the State University of Malang, which has funded this research on PNBP 2017.

\section{REFERENCES}

[1] Ifa, M. 2013. Penerapan Model Pembelajaran Kooperatif Tipe Jigsaw untuk Meningkatkan Hasil Belajar Siswa Kelas X SMK Negeri 3 Boyolangu pada Standar Kompetensi Menerapkan Keselamatan dan Kesehatan Kerja (K3). Jurnal Pendidikan Teknik Elektro, 2(2), 715722 .
[2] Sjukur, S. B. 2012. Pengaruh Blended Learning terhadap Motivasi Belajar dan Hasil Belajar Siswa Tingkat SMK. Jurnal Pendidikan Vokasi, 2(3), 368-378.

[3] Setiawan, I. G. A. N. 2008. Penerapan Pengajaran Kontekstual Berbasis Masalah untuk Meningkatkan Hasil Belajar Biologi Siswa Kelas X-2 SMA Laboratorium Singaraja. Jurnal Penelitian dan Pengembangan Pendidikan, 2(1), 42-59.

[4] Gunawan, I. 2016. Manajemen Kelas. Malang: State University of Malang, UM Press.

[5] Gunawan, I. 2017. Penerapan Manajemen Pembelajaran Berbasis Lesson Study dan Dampaknya terhadap Keaktifan Mahasiswa dalam Perkuliahan. Jurnal Pendidikan dan Pembelajaran, 24(1), 126-138.

[6] Gunawan, I. 2007. Hubungan Keterlibatan Guru dalam Musyawarah Guru Mata Pelajaran dan Kemampuan Mengelola Kelas dengan Motivasi Belajar Siswa di SMA Negeri se-Kota Malang. Thesis. Malang: Faculty of Education State University of Malang.

[7] Gunawan, I. 2016. Pengantar Statistika Inferensial. Jakarta: Rajawali Pers.

[8] Gunawan, I. 2013. Statistika untuk Kependidikan Sekolah Dasar. Yogyakarta: Ombak Yogyakarta.

[9] Wiyono, B. B., and Sunarni. 2009. Evaluasi Program Pendidikan dan Pembelajaran. Malang: Faculty of Education State University of Malang.

[10] Sarstedt, M., and Mooi, E. 2014. A Concise Guide to Market Research: The Process, Data, and Methods Using IBM SPSS Statistics. New York: Springer.

[11] Santoso, S. 2000. Buku Latihan SPSS Statistik Parametrik. Jakarta: Gramedia.

[12] Tarigan, N. 2015. Perbedaan Hasil Belajar antara Metode Behavior Modification dengan Metode Guided Discovery pada Materi Bilangan Bulat bagi Siswa Kelas VII di SMP Swasta HKBP Sidorame Tahun Ajaran 2014 / 2015. Thesis. Medan: State University of Medan.

[13] Nasution, N., and Panggabean, L. O. 2017. Perbedaan Hasil Belajar Matematika Siswa yang Diajar dengan Metode Behavior Modification dan Metode Guided Discovery pada Sub Pokok Bahasan Persamaan Kuadrat di Kelas X SMA Negeri 1 Perbaungan. Proceedings National Seminar on Matematika: Peran Alumni Matematika dalam Membangun Jejaring Kerja dan Peningkatan Kualitas Pendidikan, Faculty of Mathematics State University of Medan, Medan, 6 May, p. 666-669.

[14] Arends, R. I. 2012. Learning to Teach. New York: McGraw-Hill.

[15] Tarsih, U., Sudjarwo, and Hasyim, A. 2017. Perubahan Perilaku Belajar Siswa dalam Pembelajaran PKn Menggunakan Model Pertemuan Kelas. Retrieved June 27, 2018, from https://media.neliti.com/media/publications/40930-ID-perubahanperilaku-belajar-siswa-dalam-pembelajaran-pkn-menggunakanmodel-pertem.pdf).

[16] Fitroini, R. 2016. Penggunaan Model Pembelajaran Inquiri Terbimbing untuk Meningkatkan Sikap Mandiri dan Hasil Belajar Siswa Kelas IV SDN Leuwipanjang Bandung (Penelitian Tindakan Kelas Tema 5 Pahlawanku Sub Tema 1 Perjuangan para Pahlawan di Kelas IV SD2015/2016). Thesis. Bandung: Pasundan University.

[17] Lunanta, L. P. 2017. Modifikasi Perilaku. Retrieved June 27, 2018, from http://psi313.weblog.esaunggul.ac.id/wpcontent/uploads/sites/6825/2017/08/PPT-UEU-Modifikasi-PerilakuPertemuan-1.pptx).

[18] Mardiyah, K., and Setiawati, D. 2014. Penerapan Konseling Kelompok Cognitive Behaviour Modification (CBM) untuk Meningkatkan Tanggung Jawab dalam Belajar Siswa Kelas X-APH (Akomodasi Perhotelan) di SMK Gema 45 Surabaya. Jurnal Bimbingan dan Konseling, 4(3), 1-7.

[19] Gunawan, I. 2007. Hubungan Keterlibatan Guru dalam Musyawarah Guru Mata Pelajaran dan Kemampuan Mengelola Kelas dengan Motivasi Belajar Siswa di SMA Negeri se-Kota Malang. Thesis. Malang: Faculty of Education State University of Malang.

[20] Mardiyah, K., and Setiawati, D. 2014. Penerapan Konseling Kelompok Cognitive Behaviour Modification (CBM) untuk Meningkatkan Tanggung Jawab dalam Belajar Siswa Kelas X-APH (Akomodasi Perhotelan) di SMK Gema 45 Surabaya. Jurnal Bimbingan dan Konseling, 4(3), 1-7.

[21] Aryani, F. 2008. Efektivitas Pendekatan Cognitive Behavior Modification (CBM) untuk Mengelola Stres Belajar Siswa. Dissertation. Malang: State University of Malang. 
[22] Syarifuddin, A. 2011. Penerapan Model Pembelajaran Cooperative Belajar dan Faktor-Faktor yang Mempengaruhinya. Ta'dib, 16(1), 113-136.

[23] Gunawan, I., and Benty, D. D. N. 2007. Musyawarah Guru Mata Pelajaran dan Kemampuan Mengelola Kelas untuk Meningkatkan Motivasi Belajar Siswa. Manajemen Pendidikan, 20(1), 21-31.
[24] Silitonga, J. 2013. Pendekatan dalam Pengelolaan Kelas. Retrieved June 27, 2018, from http://www.academia.edu/4523746/PENDEKATAN_DALAM_PEN GELOLAAN_KELAS). 